\title{
Massive wood material for sustainable building design: the Massiv-Holz-Mauer wall system
}

\author{
Silvia Santi ${ }^{1}$ - Francesca Pierobon $^{2} \cdot$ Giulia Corradini $^{1} \cdot$ Raffaele Cavalli $^{1}$. \\ Michela Zanetti ${ }^{1}$
}

Received: 19 February 2016/Accepted: 10 June 2016/Published online: 28 June 2016

(C) The Japan Wood Research Society 2016

\begin{abstract}
In this study, the emissions to air produced using massive wood material in manufacturing of a MassivHolz-Mauer (MHM) wall system have been assessed. The results have been compared with a traditional brick wall. The sustainability of materials was determined using the following impact categories: global warming potential (GWP), ozone depletion potential (ODP), photochemical ozone creation potential (POCP) and human toxicity potential (HTP). Using wood material in building design can reduce the environmental impact to air up to $59 \%$ compared to using traditional material such as brick. The major contributions to the emissions of the MHM wall production are related to the sawmill process, to the manufacturing of fibreboards and aluminium nails. Furthermore, a displacement factor of $0.52 \mathrm{t} \mathrm{CO}_{2 \mathrm{eq}}$ per ton of oven-dried wood for MHM building system used in place of the brick wall was determined for the considered system boundaries.
\end{abstract}

Keywords Wood - MHM - LCA · Cross-laminated timber

Michela Zanetti

michela.zanetti@unipd.it

1 Department of Land, Environment, Agriculture and Forestry, Università degli Studi di Padova, Viale dell'Università 16, 35020 Legnaro, Padova, Italy

2 Center for International Trade in Forest Products, School of Environmental and Forest Sciences, University of Washington, Seattle, WA 98195, USA

\section{Introduction}

The construction industry is an energy-intensive sector rapidly growing in both developed and developing countries [1]. At global level building construction consumes $24 \%$ of the raw materials extracted from the lithosphere [2]. High levels of emissions from the building industry are the result of the energy consumed during the extraction, processing and transportation of materials [3]. According to the Intergovernmental Panel of Climate Change (IPCC) Fifth Assessment Report, in 2010 buildings accounted for $19 \%$ of the energy-related greenhouse gas (GHG) emissions (including electricity) [4]. The demand for energy in the life cycle of buildings is both direct and indirect. Direct energy is used for construction, operation, renovation, and demolition, while indirect energy is consumed by a building for the production of the materials used in its construction and technical installations [5]. To reduce this demand, the use of renewable materials, e.g., wood, represents an effective solution [6-8].

Wood material plays an important role in the modern economy as an alternative to traditional building materials, because of its technological qualities [9]. Wood is, in fact, both light and mechanically resistant, has a good thermal conductivity coefficient, creates a comfortable environment and has good thermal and noise insulation properties. In general, timber-based building systems can be divided into:

- Blockbau systems (or log-haus, blockhaus, etc.), structural systems representing a technology of ancient origins, but used in modern practice for the construction of residential and commercial buildings, generally up to two levels. These structures are commonly obtained by assembling multiple timber logs stacked horizontally one upon each other [10]; 
- Timber frame systems (or shear walls) which are, in most of Europe, usually prefabricated elements. They consist of a timber frame, with hinged connections, sheathed by wood-based panels connected to the frame by metal fasteners [11];

- Cross-laminated timber (CLT) systems (called also "XLam," "Massive Timber" or "Cross-Lam"). In these systems, boards are glued side by side in a single layer and then glued to another layer of boards placed at right angles with the adjacent layers [12]. The crosslamination design improves rigidity, stability, and mechanical properties. Compared to the other systems, the CLT presents several advantages: speed and efficiency of installation, thanks to the prefabrication; design flexibility; cost competitiveness; fire protection; seismic performance; thermal performance and energy efficiency; resource efficiency-it can use smallerdimension material that might not otherwise be used in structural applications [13]. Furthermore, CLT structures could prove to be a viable alternative to concrete and steel for mid- to high-rise buildings [14].

Within the CLT systems group, a new building system, called Massiv-Holz-Mauer (MHM), has been patented in Germany in 2005. In MHM building system, the crossed layers of boards are jointed by aluminium screws and no adhesives are used. The specifications of MHM walls can be found in the European Technical Approval (ETA) for MHM [15]. Its production line, nearly entirely automatic, is described on the Hundegger website [16].

Wood is commonly regarded as the most environmentally friendly material in building design and construction [17]. Several studies have demonstrated that the use of wood for building in substitution to other materials causes less GHG emissions [2, 18-22]. A review and synthesis of various international studies on wood products concludes that manufacturing wood products requires less total energy, and in particular less fossil energy, than manufacturing most alternative materials. Cradle-to-gate analyses of material production, including the acquisition of raw materials, transportation, and processing into usable products, show that wood products need less production energy than a functionally equivalent amount of metal, concrete or bricks [23]. Furthermore, recent studies also indicate that wood-based wall systems entail 10-20\% less embodied energy than traditional concrete systems [24, 25].

The lower environmental impacts of wood products compared to other materials are also related to the fact that the carbon dioxide released in the combustion phase at the end of the product life equals the carbon dioxide absorbed during the growth of a same amount of biomass in forest (carbon neutrality assumption) [26, 27]. Moreover, long- lasting wood products, e.g., wood products for buildings, have an additional benefit on climate change, since during their entire lifetime they act like temporary $\mathrm{CO}_{2}$ storages, storing carbon in their biomass that would have otherwise been emitted to the atmosphere [2, 28]. Lastly, using wood products at their end of life as a substitute energy source, the emissions from other sources, such as fossil fuels, could be reduced [29]. When comparing the overall environmental impacts of wood products with traditional materials, a meta-analysis of the displacement factors of wood products substituted in place of non-wood materials observes an average displacement factor value of 2.1 [30].

In literature several studies have been carried out on CLT environmental performances [31-35]; however, the authors are not aware of any previous research carried out on the environmental impacts of the MHM system, besides a compendium of wood products and technologies in construction funded by the Australian government which emphasized the absence of glue in this building system [36]. Since MHM represents an innovative and recent building system (its licence was submitted in 2012) its environmental advantages have not been yet studied. Improved knowledge of the environmental impacts of the materials and processes associated with productive sectors including the wood-based sector is a key factor in guiding efforts towards green production processes and green markets [37]. In this framework, the objective of this study is to perform a comparative cradle-to-gate life cycle assessment (LCA) in order to evaluate the environmental impacts in terms of emissions to air produced from materials used in the construction of an MHM wall system and a brick wall one.

\section{Materials and methods}

In Italy, the most requested MHM wall system for the construction of individual dwelling houses is $28.5 \mathrm{~cm}$ thick. From the inside to the outside, the wall system consists of the following materials: plasterboard, 9 Norway spruce (Picea abies L.) layers of boards connected by aluminium nails, transpiring geotextile, insulating fibreboards $(2 \times 40 \mathrm{~cm})$, mortar, plaster mesh, and plaster for outer covering (corresponding, respectively, to letters a-g in Fig. 1a). The Norway spruce boards have a water content of $13 \%$, a density of $480 \mathrm{~kg} \mathrm{~m}^{-3}$ and a thickness of $23 \mathrm{~mm}$. The thermal transmittance ( $U$ value) of the 28.5cm-thick MHM wall system is $0.21 \mathrm{~W} \mathrm{~m}^{-2} \mathrm{~K}^{-1}$.

For the comparison, an exterior brick wall able to ensure the same thermal transmittance characteristics has been used. The brick wall used for comparison is $40 \mathrm{~cm}$ thick, which is a widely used wall system in Italy for the construction of individual dwelling houses [39]. Its elements 
Fig. 1 A Massiv-Holz-Mauer (MHM) wall system ( $a$ plasterboard, $b$ 9-layer spruce boards, $c$ geotextile, $d$ fibreboards, $e$ mortar, $f$ plaster mesh, $g$ plaster) [38]; B brick wall system ( $a$ lime and cement plaster layer; $b$ perforated clay bricks + mortar on the horizontal surfaces of the bricks, $c$ insulating panel in extruded polystyrene foam (XPS), $d$ lime and cement mortar layer

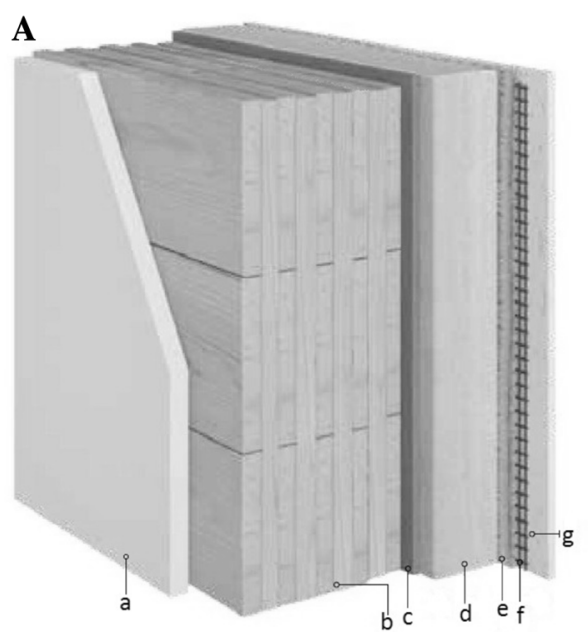

B

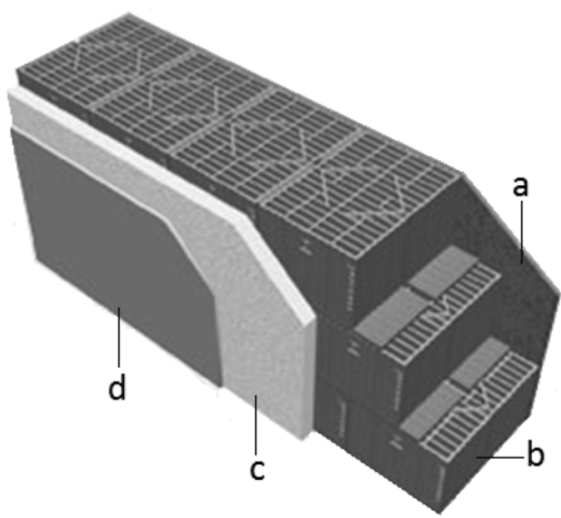

are: plaster, perforated clay bricks with mortar on their horizontal surfaces, insulating panel of extruded polystyrene foam (XPS), and mortar for outer covering (Fig. 1b). The weight of $1 \mathrm{~m}^{2}$ of MHM system is $128 \mathrm{~kg}$ while the weight of $1 \mathrm{~m}^{2}$ brick wall is $313 \mathrm{~kg}$.

Data collection included both primary and secondary data. Tables 1 and 2 detail the inputs and outputs of MHM and brick LCA models. In the MHM wall, the Norway spruce wood density at $50 \%$ of moisture content is assumed to be $750 \mathrm{~kg} \mathrm{~m}^{-3}$ until the boards air drying process. After air drying the moisture content decreases to $12 \%$ and the density changes to $480 \mathrm{~kg} \mathrm{~m}^{-3}$. The trees are motor manual felled by a chainsaw (tree felling) and then hauled as full tree for a short distance $(50 \mathrm{~m})$ by tractor equipped with a winch (extraction). Chainsaw is the most used equipment in North Eastern Italy for tree felling. The wood harvesting produces $30 \%$ of residues which are left to decompose in forest. Forest operations are then performed by means of a chainsaw to transform full tree in logs (landing) which are transported with a 32-t payload EURO5 truck to the sawmill.

Primary data on quantities of materials and energy needed to produce and transport wooden boards to build $1 \mathrm{~m}^{2}$ of MHM wall have been collected in 2015. Information has been provided by a sawmill and by a construction company. The selected companies, in terms of use of material, production processes and energy mix utilized, are representative of the sectorial Italian small and medium enterprises. Data about energy and fuel used to make MHM boards were calculated as a percentage on the total consumptions of the sawmill. This percentage was considered equivalent to the percentage of MHM boards processed in 1 year $\left(400 \mathrm{~m}^{3}\right)$ on the total production of the sawmill. This resulted in $0.6 \mathrm{~L}$ of diesel and $13 \mathrm{kWh}$ of electricity (31\% from renewable sources) for $1 \mathrm{~m}^{2} \times 9$ layers of wood necessary to build $1 \mathrm{~m}^{2}$ of MHM. On the other hand assembling energy at the company is $10 \mathrm{kWh}$ for $1 \mathrm{~m}^{2}$ of wall. The planks are transported by truck for $186 \mathrm{~km}$ from the sawmill to the MHM producing company where the timber walls are assembled; other transportation means are not suitable for this short distance.

Secondary data were used for the production processes of the other materials necessary to build an MHM wall and for all the components, processes and transports of the brick wall (Tables 1,2). These data were provided by the Ecoinvent database [40].

LCA was used to assess the environmental impact of the studied materials. LCA is a standardized and worldwide recognized methodology. This technique enables the environmental performance of materials to be evaluated during their entire life cycle [37, 41, 42].

GaBi 6 software was used to perform the analysis, to generate the emission factors and to analyze the relative contribution of the processes to the total emissions. GaBi 6 is a software package developed by PE International designed for analyzing the environmental impact of products and services [43].

The functional unit is for both systems $1 \mathrm{~m}^{2}$ of exterior wall, ensuring a thermal transmittance of $0.21 \mathrm{~W} \mathrm{~m}^{-2} \mathrm{~K}^{-1}$. The investigated system boundaries for both systems are defined to be cradle-to-gate. They include life cycle stages from the extraction or acquisition of raw materials to the point at which the product leaves the organization undertaking the assessment [44].

The system boundaries for MHM and for brick wall building systems are illustrated, respectively, in Figs. 2 and 3. Specific information about energy and fuel flows is reported in Tables 1 and 2. For both the systems four impact categories were determined using the impact assessment method of the Institute of Environmental Science of Leiden University (CML) 2001-Apr. 2013 methodology: global warming potential (GWP), OZONE DEPLETION POTENTIAL (ODP), photochemical ozone creation potential (POCP) and human toxicity potential 
Table 1 Flows (inputs and outputs) of $1 \mathrm{~m}^{2}$ Massiv-Holz-Mauer (MHM) wall manufacturing processes

\begin{tabular}{|c|c|c|}
\hline Wooden boards & Input & Output \\
\hline Tree feeling & $\begin{array}{l}\text { Spruce tree in forest }\left(0.386 \mathrm{~m}^{3}\right) \\
\text { Energy (diesel) consumed by a } 3.6-\mathrm{kW} \text { chainsaw to } \\
\text { manual felling the tree (time: } 0.035 \mathrm{~h} \text { ) }\end{array}$ & $\begin{array}{l}\text { Felled spruce tree }\left(0.297 \mathrm{~m}^{3}\right) \text { without branches } \\
\text { [Tree waste }\left(0.062 \mathrm{~m}^{3}\right) \text { not taken into account in } \\
\text { the LCA }{ }^{\mathrm{a}} \text { model] }\end{array}$ \\
\hline Extraction & $\begin{array}{l}\text { Felled spruce tree }\left(0.297 \mathrm{~m}^{3}\right) \\
\text { Energy (diesel) consumed by a } 4 \text { wheel drive } 67-\mathrm{kW} \\
\text { tractor equipped with a winch to extract the felled } \\
\text { tree-distance } 50 \mathrm{~m}\end{array}$ & Felled spruce tree $\left(0.297 \mathrm{~m}^{3}\right)$ \\
\hline Landing & $\begin{array}{l}\text { Felled spruce tree }\left(0.297 \mathrm{~m}^{3}\right) \\
\text { Energy (diesel) consumed by a } 3.6-\mathrm{kW} \text { chainsaw to } \\
\quad \text { manually cut the tree }(h=0.035 \mathrm{~h})\end{array}$ & Logs $\left(0.297 \mathrm{~m}^{3}\right)$ \\
\hline Road transport to sawmill & $\begin{array}{l}\text { Logs }\left(0.297 \mathrm{~m}^{3}\right) \\
\text { Energy (diesel) consumed by a } 32-\mathrm{t} \text { payload EURO5 } \\
\text { truck to transport the logs per } 133 \mathrm{~km}\end{array}$ & Logs $\left(0.297 \mathrm{~m}^{3}-50 \%\right.$ moisture content $)$ \\
\hline Log handling at sawmill & $\begin{array}{l}\text { Logs }\left(0.297 \mathrm{~m}^{3}\right) \\
\text { Energy (diesel): } 0.27 \mathrm{~kg} \\
\text { Lubricant: } 0.0061 \mathrm{~kg}\end{array}$ & Logs $\left(0.297 \mathrm{~m}^{3}-50 \%\right.$ moisture content $)$ \\
\hline Log processing at sawmill & $\begin{array}{l}\text { Logs }\left(0.297 \mathrm{~m}^{3}\right) \\
\text { Energy (diesel): } 0.0073 \mathrm{~kg} \\
\text { Energy (electricity mix): } 47.07 \mathrm{MJ} \\
\text { Lubricant: } 4.00 \mathrm{E}-07 \mathrm{~kg}\end{array}$ & $\begin{array}{l}\text { Boards }\left(0.297 \mathrm{~m}^{3}\right) \\
\text { [Saw dust }\left(0.025 \mathrm{~m}^{3}\right)+\text { wood chips }\left(0.065 \mathrm{~m}^{3}\right) \\
\text { not taken into account in the LCA model] }\end{array}$ \\
\hline Boards air drying & Boards $\left(0.297 \mathrm{~m}^{3}\right.$ at $50 \%$ moisture content $)$ & Boards $\left(0.207 \mathrm{~m}^{3}\right.$ at $12 \%$ moisture content $)$ \\
\hline Boards handling with machine & $\begin{array}{l}\text { Boards }\left(0.207 \mathrm{~m}^{3}\right) \\
\text { Energy (diesel): } 0.46 \mathrm{~kg} \\
\text { Lubricant: } 0.108 \mathrm{~kg}\end{array}$ & Boards $\left(0.207 \mathrm{~m}^{3}\right)$ \\
\hline Boards transport to the company & $\begin{array}{l}\text { Boards }\left(0.207 \mathrm{~m}^{3}\right) \\
\text { Energy (diesel) consumed by a 32-t payload EURO5 } \\
\quad \text { truck to transport the boards per } 166 \mathrm{~km}\end{array}$ & Boards $\left(0.207 \mathrm{~m}^{3}\right)$ \\
\hline Aluminium nails & $\begin{array}{l}\text { RER }^{\mathrm{b}} \text { : metal working, average for aluminium } \\
\text { product manufacturing } \\
\text { Energy (diesel) consumed by a } 32-\mathrm{t} \text { payload EURO5 } \\
\text { truck to transport the aluminium nails per } 600 \mathrm{~km}\end{array}$ & Aluminium nails $(0.7 \mathrm{~kg})$ \\
\hline Plasterboard & $\begin{array}{l}\mathrm{CH}^{\mathrm{c}} \text { : gypsum plasterboard production } \\
\text { Energy (diesel) consumed by a } 16-32 \mathrm{t} \text { payload } \\
\text { EURO5 truck to transport the plasterboard per } \\
200 \mathrm{~km}\end{array}$ & Plasterboard $(9.5 \mathrm{~kg})$ \\
\hline Geotextile & $\begin{array}{l}\text { RER: fleece production, polyethylene } \\
\text { Energy (diesel) consumed by a } 16-32 \mathrm{t} \text { payload } \\
\text { EURO5 truck to transport the geotextile per } \\
150 \mathrm{~km}\end{array}$ & Geotextile $(0.15 \mathrm{~kg})$ \\
\hline Fibreboard & $\begin{array}{l}\mathrm{CH} \text { : fibreboard production, soft, from wet processes } \\
\text { Energy (diesel) consumed by a 32-t payload EURO5 } \\
\text { truck to transport the geotextile per } 600 \mathrm{~km}\end{array}$ & Fibreboard $\left(0.08 \mathrm{~m}^{3}\right)$ \\
\hline Mortar & $\begin{array}{l}\mathrm{RoW}^{\mathrm{d}} \text { : cement mortar production } \\
\text { Energy (diesel) consumed by a } 32-\mathrm{t} \text { payload EURO5 } \\
\quad \text { truck to transport the mortar per } 200 \mathrm{~km}\end{array}$ & Mortar $(6 \mathrm{~kg})$ \\
\hline Plaster mesh & $\begin{array}{l}\text { RER: glass fiber production } \\
\text { Energy (diesel) consumed by a 32-t payload EURO5 } \\
\text { truck to transport the plaster mesh per } 200 \mathrm{~km}\end{array}$ & Plaster mesh $(0.15 \mathrm{~kg})$ \\
\hline Plaster & $\begin{array}{l}\mathrm{CH} \text { : cover plaster production, mineral } \\
\text { Energy (diesel) consumed by a } 32-\mathrm{t} \text { payload EURO5 } \\
\text { truck to transport the plaster per } 200 \mathrm{~km}\end{array}$ & Plaster $(2.5 \mathrm{~kg})$ \\
\hline
\end{tabular}


Table 1 continued

\begin{tabular}{lll}
\hline Wooden boards & Input & Output \\
\hline MHM assembling & IT $^{\mathrm{e}}$ : energy production photovoltaic, 3KWp slanted- & $1 \mathrm{~m}^{2}$ of MHM wall \\
& roof installation, single-Si, panel, mounted- \\
& \\
& IT: electricity, high voltage, production mix- \\
& $25.2 \mathrm{MJ}$ \\
\hline
\end{tabular}

${ }^{\text {a }}$ Life cycle assessment

b Europe

c Switzerland

${ }^{\mathrm{d}}$ Rest of the world

e Italy

(HTP). The time frame for the assessment of the global warming impact was 100 years, as recommended by the Publicly Available Specification (PAS) 2050 [44].

Lastly, a displacement factor was calculated to quantify the amount of emission reduction achieved per unit of

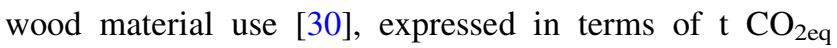
emission reduction per $\mathrm{t}$ of oven-dry wood product.

\section{Results}

\section{Environmental assessment of materials used to produce $1 \mathrm{~m}^{2}$ of MHM wall}

The results of the LCA model for the MHM wall production processes are summarized in Table 3.

In terms of GWP, the production of $1 \mathrm{~m}^{2}$ of MHM emits $35.23 \mathrm{~kg} \mathrm{CO}$ eq. The main processes which contribute to it are: the sawmill process $(31 \%)$, the fibreboards manufacturing $(22 \%)$ and the electricity production for the final assembling of the wall (14\%). The energy-related emissions are almost totally due to the non-renewable electricity production. The sawmill process produces $10.74 \mathrm{~kg} \mathrm{CO}_{2 \mathrm{eq}}$. The log processing is responsible for $82 \%$ of the emissions: this amount is again caused by the electricity production mix.

Concerning the ODP, producing $1 \mathrm{~m}^{2}$ of MHM generates $4.37 \mathrm{mg} \mathrm{R} 11_{\mathrm{eq}}$. The main processes influencing the ODP emissions are the sawmill process, the fibreboard phase and the energy production for MHM assembling.

At local scale, POCP results in $32.19 \mathrm{~g}$ ethene $\mathrm{eq}_{\mathrm{e}}$ and it is mainly caused by the forest operations (57\%) mainly due to the use of chainsaw for tree felling and landing operations. Sawmill and fibreboard processes also affect this impact category, producing 14 and $10 \%$ of POCP gases, respectively.

As POCP, HTP (9.71 kg DCB eq ) shows a slightly more uniform distribution of emissions between electricity
(8\%), plaster mesh and fibreboards manufacturing (15\%) and sawmill processes (17\%), but aluminium manufacturing is the main pollutant process in terms of HTP (30\%).

While it is difficult to suggest improvements to reduce emissions connected to the soft fibreboard, plaster mesh and aluminium manufacturing, measures could be taken to reduce sawmill and assembling-related emissions. In both cases a larger amount of renewable energy could be used instead of electricity from non-renewable sources; the producer could improve its photovoltaic panels system for this purpose. If the totality of the $10 \mathrm{kWh}$ needed to assemble $1 \mathrm{~m}^{2}$ of wall was from photovoltaic source, the GWP emissions related to electricity would decrease by $84 \%$ and the overall GWP emissions for MHM would decrease by $2 \%$.

Except for forest operations, where the transport phase accounts for $85 \%$ of GWP, it is remarkable that for all impact categories and for all materials needed to build $1 \mathrm{~m}^{2}$ of $\mathrm{MHM}$ it is the production process, and not the transport, that accounts for the largest percentage of emissions, even though the transport distances are sometimes considerable (e.g., $600 \mathrm{~km}$ for aluminium nails and fibreboards). This is due to the light weight of these materials (e.g., $0.7 \mathrm{~kg}$ aluminium nails and $10.8 \mathrm{~kg}$ fibreboards per functional unit). The wooden boards transport contributes to GWP with $13 \%$ emissions of $\mathrm{CO}_{2 \mathrm{eq}}$ on the total $\mathrm{CO}_{2 \mathrm{eq}}$ attributed to the whole sawmill process. The other materials transport-related emissions vary between $0.7 \%$ (plaster mesh) and $11 \%$ (plaster) $\mathrm{CO}_{2 \text { eq }}$ of the total emissions relative to the production of each material. The higher value for the wooden boards is due to the greater quantity of wood needed for $1 \mathrm{~m}^{2}$ of MHM. In any case the emissions related to transport would increase if the sawn wood was bought further away, meaning that the local production chain should be encouraged in order to keep the transport environmental impact as low as possible. 
Table 2 Flows (inputs and outputs) of $1 \mathrm{~m}^{2}$ brick wall manufacturing processes

\begin{tabular}{|c|c|c|}
\hline & Input & Output \\
\hline Brick & $\begin{array}{l}\text { RER }^{\mathrm{a}} \text { : brick production } \\
\text { Energy (diesel) consumed by a } 32 \text {-t payload EURO5 truck } \\
\text { to transport the bricks per } 84.2 \mathrm{~km}\end{array}$ & Bricks $(227 \mathrm{~kg})$ \\
\hline Plaster & $\begin{array}{l}\text { RER: cover plaster production, mineral } \\
\text { Energy (diesel) consumed by a } 32-\mathrm{t} \text { payload EURO5 truck } \\
\text { to transport the plaster per } 200 \mathrm{~km}\end{array}$ & Plaster $(27 \mathrm{~kg})$ \\
\hline Light mortar & $\begin{array}{l}\mathrm{CH}^{\mathrm{b}} \text { : light mortar production } \\
\text { Energy (diesel) consumed by a } 32-\mathrm{t} \text { payload EURO5 truck } \\
\text { to transport the light mortar per } 342 \mathrm{~km}\end{array}$ & Light mortar $(1 \mathrm{~kg})$ \\
\hline Polystyrene XPS panels & $\begin{array}{l}\mathrm{CH} \text { : polystyrene foam slab for perimeter insulation } \\
\text { Energy (diesel) consumed by a } 32-\mathrm{t} \text { payload EURO5 truck } \\
\text { to transport the polystyrene XPS panel per } 264 \mathrm{~km}\end{array}$ & Polystyrene $\mathrm{XPS}^{\mathrm{c}}$ panels $(2.4 \mathrm{~kg})$ \\
\hline Mortar & $\begin{array}{l}\mathrm{CH} \text { : cement mortar production } \\
\text { Energy (diesel) consumed by a } 32-\mathrm{t} \text { payload EURO5 truck } \\
\text { to transport the mortar per } 200 \mathrm{~km}\end{array}$ & Mortar $(5.4 \mathrm{~kg})$ \\
\hline Brick wall assembling (manually) & $\begin{array}{l}\text { Bricks }+ \text { plaster }+ \text { light mortar }+ \text { polystyrene XPS } \\
\text { panels }+ \text { mortar }\end{array}$ & $1 \mathrm{~m}^{2}$ of brick wall \\
\hline
\end{tabular}

\footnotetext{
${ }^{\text {a }}$ Europe

${ }^{b}$ Switzerland

${ }^{\mathrm{c}}$ Extruded polystyrene foam
}

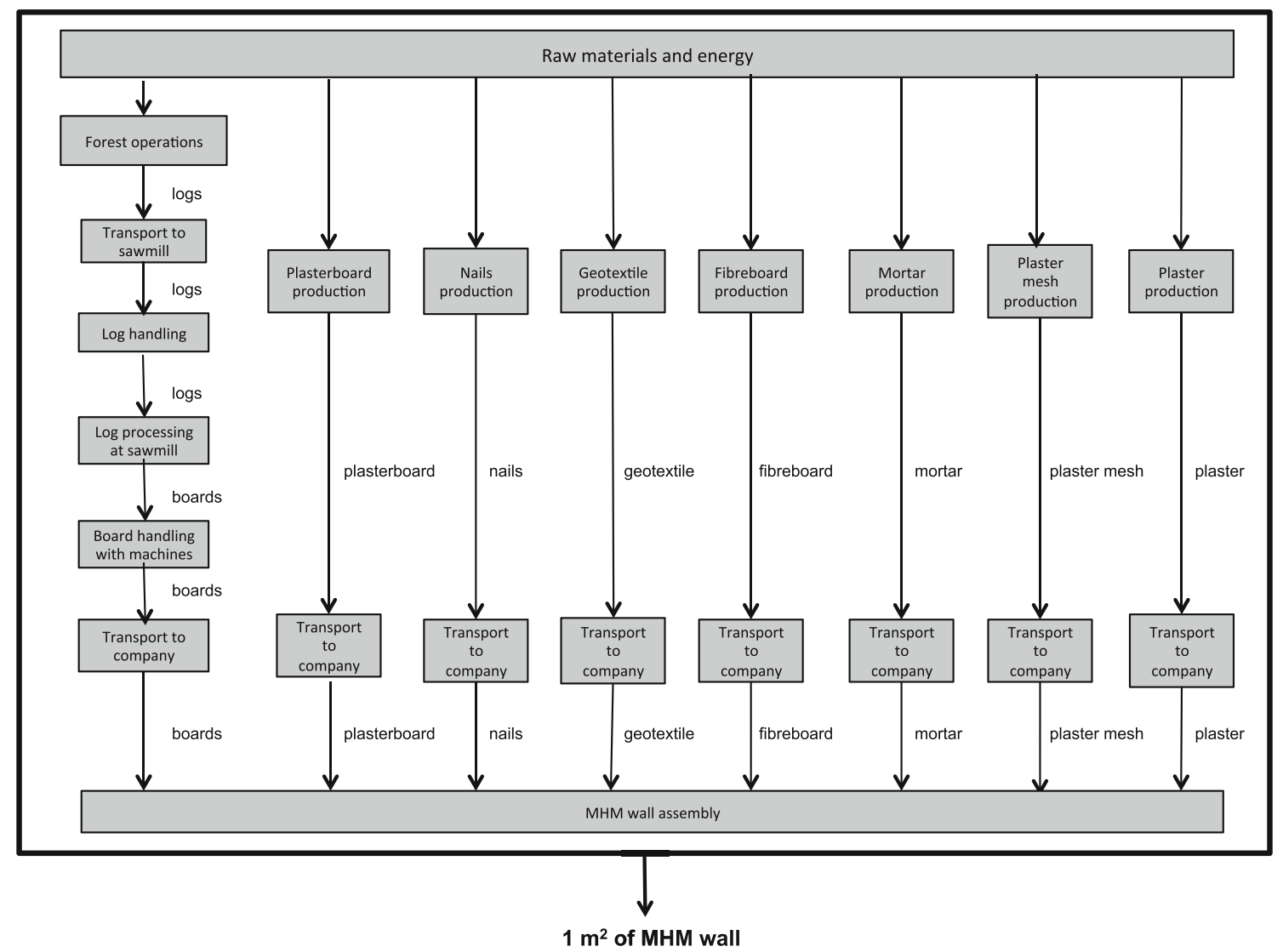

Fig. 2 Cradle-to-gate system boundaries for Massiv-Holz-Mauer (MHM) wall system 


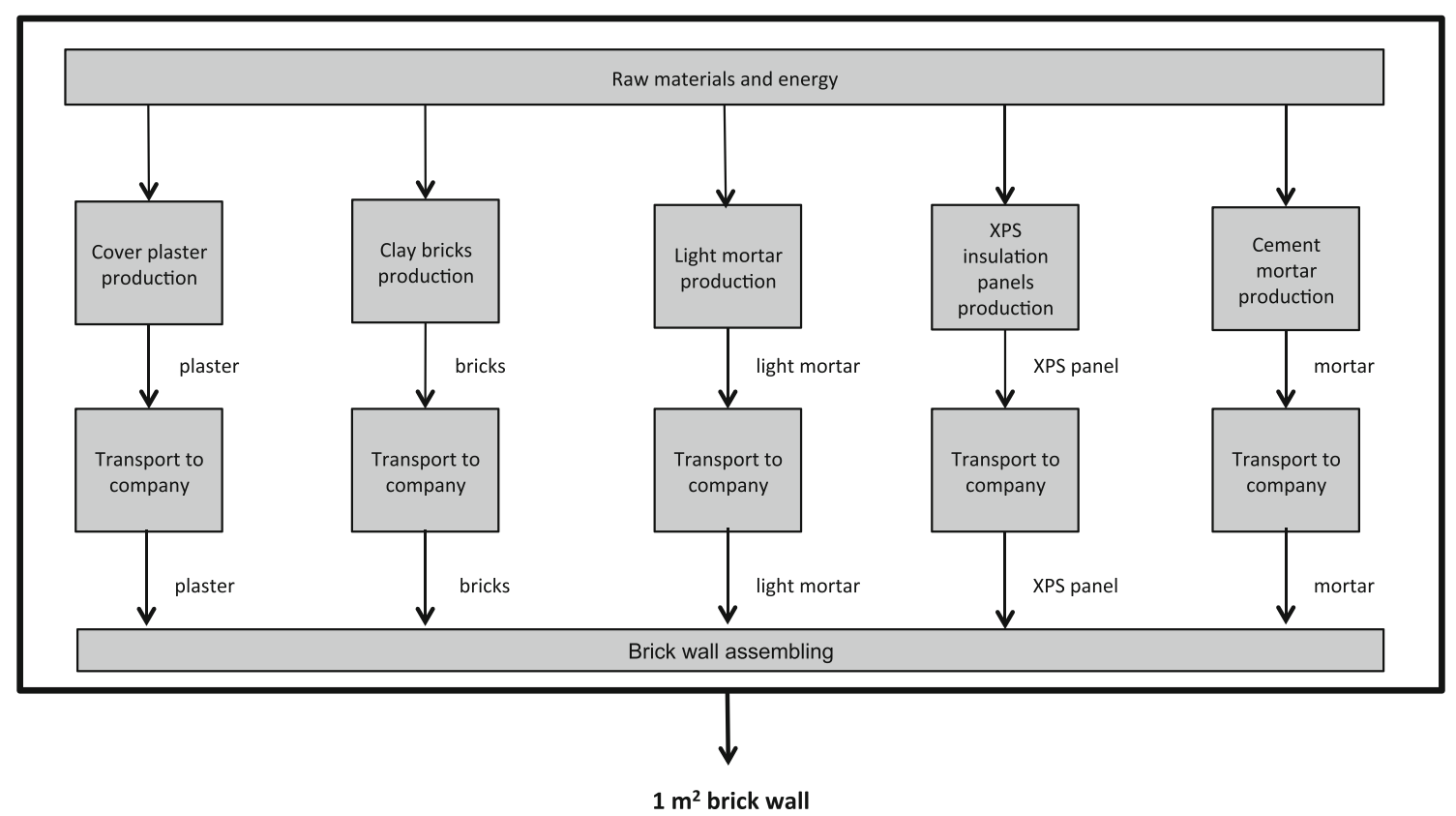

Fig. 3 Cradle-to-gate system boundaries for brick wall system

\section{Comparison between MHM and brick wall}

Figure 4 shows the comparison of the overall impact of the two production processes. The wooden building system shows a better environmental performance for all the analyzed impact categories. Table 4 shows the contribution of brick wall materials production processes to the four impact categories considered in this study. The GWP of the brick wall $\left(85.90 \mathrm{~kg} \mathrm{CO}_{2 \mathrm{eq}}\right)$ is more than double than the GWP of MHM (35.23 kg CO $\mathrm{CO}_{2 \mathrm{eq}}$ ). As wrote before, the POCP value of forest operations is affected by the emissions of chainsaw but the MHM still performs better than brick with $9.45 \mathrm{~g}$ ethene $\mathrm{eq}_{\text {e }}$ less. ODP and HTP of MHM are, respectively, 40 and $50 \%$ lower than brick wall. In fact, the brick wall provides $7.32 \mathrm{mg} \mathrm{R} 11_{\mathrm{eq}}$ against $4.38 \mathrm{mg} \mathrm{R} 11_{\mathrm{eq}}$ and $19.46 \mathrm{~kg} \mathrm{DCB}_{\mathrm{eq}}$ (1,4-dichlorobenzene) instead of $9.71 \mathrm{~kg} \mathrm{DCB}$ eq of MHM.

To better understand the contributions to the four impact categories of the production of $1 \mathrm{~m}^{2}$ of MHM and brick wall, Table 5 shows the list and values of the emitted chemicals. The two columns "characterization" and "inventory" represent, respectively, the results after and before characterization (the phase of the LCA which attributes the impact of different chemicals in terms of a reference gas). Note that in Ecoinvent long-term emissions are defined as emissions occurring more than 100 years after present.

Carbon dioxide is the main contributor to GWP, with $27.61 \mathrm{~kg} \mathrm{CO}_{2}$ for MHM and $78.93 \mathrm{~kg} \mathrm{CO}_{2}$ for the brick wall. The main sources of non-biotic carbon are fossil fuel combustion in industrial processes and in electricity production. Compared to fossil carbon, biogenic carbon is emitted in minor quantity. Biogenic carbon dioxide emitted from brick wall production is lower $\left(1.85 \mathrm{~kg} \mathrm{CO}_{2}\right)$ than that of MHM wall since no wood biomass is involved in its production, while MHM biogenic $\mathrm{CO}_{2}\left(4.95 \mathrm{~kg} \mathrm{CO}_{2}\right)$ is mainly related to the fibreboards production. The method of evaluation of the biogenic emissions is still object of discussion at international level. Based on international standards and guidelines, the biogenic carbon dioxide is not accounted in LCA studies (carbon neutrality assumption) or is reported separately [45]. In this work the second option has been chosen. Methane has a GWP of 28 for a time horizon of 100 years [46] and is indeed the third highest greenhouse gas that is produced from both MHM $(1.99 \mathrm{~kg})$ and brick wall building systems $(4.64 \mathrm{~kg})$. Methane emissions for the brick wall are mainly caused by brick and polystyrene slabs production, while for MHM the main methane emitting processes are electricity from non-renewable sources and aluminium manufacturing. The amount of nitrous oxide $\left(\mathrm{N}_{2} \mathrm{O}\right)$ and sulphur hexafluoride $\left(\mathrm{SF}_{6}\right)$ emissions contributing to GWP derive from industrial activities and combustion and are comparable between the two processes. On the other hand, halogenated gases [chlorofluorocarbons (CFCs), hydrofluorocarbons (HFCs), hydrochlorofluorocarbons (HCFCs), perfluorocarbons (PFCs)] emissions are higher for MHM because of the aluminium manufacturing.

As mentioned above, the ODP for the MHM production process corresponds to $60 \%$ of the ODP for the brick wall (Fig. 4). Halogenated organic emissions are $4.37 \mathrm{mg} \mathrm{R} 11_{\mathrm{eq}}$ for the former and $7.32 \mathrm{mg} \mathrm{R} 11_{\mathrm{eq}}$ for the latter. Halon is the emission which mostly contributes to the total halogenated gases in both cases; it is particularly high for brick 

Massiv-Holz-Mauer (MHM) wall materials production potential (GWP), ozone depletion potential (ODP), photochemical ozone creation potential (POCP), human toxicity potential (HTP) for the production of $1 \mathrm{~m}^{2}$ of wall
Table 3 Contributions of process to global warming

\begin{tabular}{|c|c|c|c|c|}
\hline Specific contributions & $\begin{array}{l}\mathrm{GWP} \\
\left(\mathrm{kg} \mathrm{CO}_{2 \mathrm{eq}}\right)\end{array}$ & $\begin{array}{l}\text { ODP } \\
\left(\mathrm{mg} \mathrm{R} 11_{\mathrm{eq}}\right)\end{array}$ & $\begin{array}{l}\text { POCP } \\
\left(\mathrm{g} \text { Ethene }_{\mathrm{eq}}\right)\end{array}$ & $\begin{array}{l}\text { HTP } \\
\left(\mathrm{kg} \mathrm{DCB}_{\mathrm{eq}}\right)^{\mathrm{a}}\end{array}$ \\
\hline Total & 35.231 & 4.373 & 32.185 & 9.714 \\
\hline Plasterboard & 3.062 & 0.267 & 1.218 & 0.714 \\
\hline Manufacturing & 2.737 & 0.208 & 1.047 & 0.568 \\
\hline Transport & 0.325 & 0.059 & 0.171 & 0.147 \\
\hline Forest operations & 2.600 & 0.437 & 18.174 & 0.463 \\
\hline Tree felling & 0.193 & 0.037 & 8.365 & 0.054 \\
\hline Extraction & 0.002 & 0.000 & 0.002 & 0.003 \\
\hline Landing & 0.193 & 0.037 & 8.365 & 0.054 \\
\hline Road transport & 2.211 & 0.363 & 1.442 & 0.351 \\
\hline Sawmill process & 10.738 & 1.855 & 4.587 & 1.604 \\
\hline Log handling & 0.169 & 0.193 & 0.257 & 0.035 \\
\hline Log processing & 8.856 & 1.067 & 2.963 & 0.990 \\
\hline Board handling & 0.287 & 0.328 & 0.440 & 0.059 \\
\hline Transport & 1.426 & 0.267 & 0.927 & 0.519 \\
\hline Aluminium nails & 3.168 & 0.157 & 1.906 & 2.944 \\
\hline Manufacturing & 3.133 & 0.150 & 1.883 & 2.931 \\
\hline Transport & 0.036 & 0.007 & 0.023 & 0.013 \\
\hline Geotextile & 0.412 & 0.008 & 0.439 & 0.056 \\
\hline Manufacturing & 0.408 & 0.008 & 0.437 & 0.054 \\
\hline Transport & 0.004 & 0.001 & 0.002 & 0.002 \\
\hline Fibreboard & 7.560 & 0.890 & 3.189 & 1.429 \\
\hline Manufacturing & 6.988 & 0.783 & 2.817 & 1.221 \\
\hline Transport & 0.572 & 0.107 & 0.372 & 0.208 \\
\hline Mortar & 1.958 & 0.089 & 0.530 & 0.244 \\
\hline Manufacturing & 1.855 & 0.069 & 0.464 & 0.207 \\
\hline Transport & 0.102 & 0.019 & 0.066 & 0.037 \\
\hline Plaster mesh & 0.372 & 0.033 & 0.191 & 1.364 \\
\hline Manufacturing & 0.370 & 0.032 & 0.189 & 1.363 \\
\hline Transport & 0.003 & 0.001 & 0.002 & 0.001 \\
\hline Plaster & 0.389 & 0.036 & 0.187 & 0.089 \\
\hline Manufacturing & 0.347 & 0.028 & 0.159 & 0.074 \\
\hline Transport & 0.043 & 0.008 & 0.028 & 0.015 \\
\hline Assembling (electricity) & 4.973 & 0.602 & 1.762 & 0.806 \\
\hline Photovoltaic & 0.232 & 0.033 & 0.179 & 0.276 \\
\hline Non-renewable & 4.740 & 0.569 & 1.583 & 0.530 \\
\hline
\end{tabular}

a 1,4-dichlorobenzene

production (3.56 mg R11 eq of Halon 1211 and $2.87 \mathrm{mg}$ $\mathrm{R} 11_{\mathrm{eq}}$ for Halon 1301). Chemicals having an influence on the ozone depletion are emitted in a very small quantity in terms of absolute values, but they have a high ozone depletion potential.

POCP shows the maximum difference in emissions between MHM and brick product systems. In both cases, NMVOCs (non-methane volatile organic compounds) produce the largest fraction of ethane equivalent emissions. The 21.61 g ethene $_{\text {eq }}$ of MHM are mainly caused by the chainsaw used (14.14 $\mathrm{g}$ ethene $\mathrm{eq}_{\mathrm{eq}}$ ). On the other hand, it is again the brick production process which contributes the most to
$17.63 \mathrm{~g}$ ethene $e_{\text {eq }}$ of NMVOC formation for the brick wall. For most of the other chemicals with POCP (sulphur dioxide, nitrogen oxides, non-biogenic carbon monoxide and methane), emissions for MHM wall are lower than those relative to the brick wall (Table 5). Sulphur oxides and unspecified hydrocarbons emissions are similarly low.

Lastly, the HTP produced from brick wall manufacturing process is twice $(19.46 \mathrm{~kg} \mathrm{DCB} e q$ the HTP of the MHM production $\left(9.71 \mathrm{~kg} \mathrm{DCB}_{\mathrm{eq}}\right)$. Heavy metals, such as chromium (+VI), arsenic, nickel, cadmium and copper, contribute heavily to HTP impact category both for MHM and for the brick wall. Emissions of heavy metals to air are 


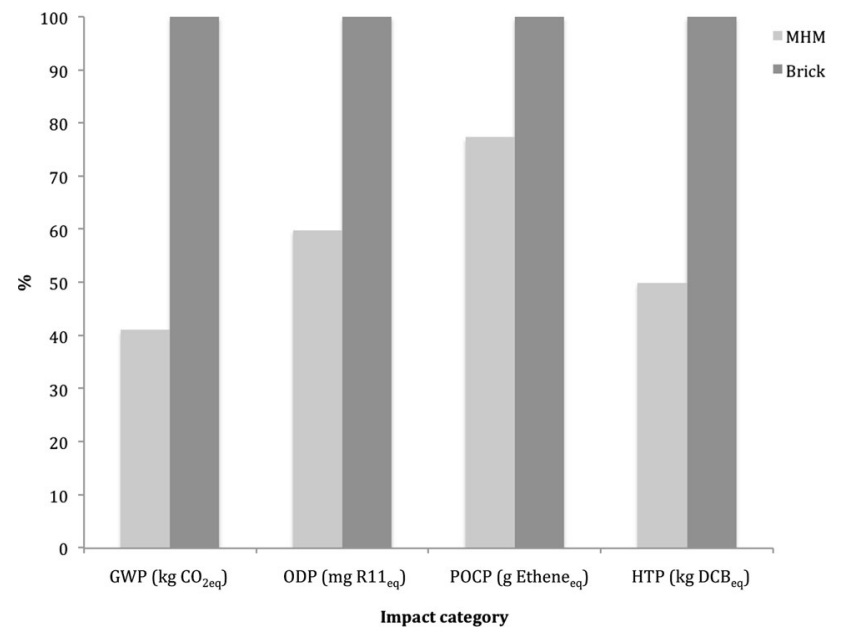

Fig. 4 Massiv-Holz-Mauer (MHM) and brick wall production processes comparison in terms of relative environmental impacts for the impact categories global warming potential (GWP), ozone depletion potential (ODP), photochemical ozone creation potential (POCP), human toxicity potential (HTP)

related to secondary aluminium industry [47] as well as to brick manufacturing [48] and are, in descending order for both MHM wall and brick wall, VOCs, inorganic emissions such as hydrogen fluoride and nitrogen oxides, long term to air emissions and particles (mainly dust $>$ PM10). This impact category includes dust particles and silicon dust, with $0.08 \mathrm{~kg} \mathrm{DCB}$ eq for the brick wall and $0.15 \mathrm{~kg} \mathrm{DCB}$ eq for MHM, where emitted particles are mainly $\mathrm{PM}>10$ caused by aluminium manufacturing $\left(0.12 \mathrm{~kg} \mathrm{DCB} \mathrm{Dq}_{\mathrm{eq}}\right)$.

\section{Displacement factor}

$1 \mathrm{~m}^{2}$ of MHM wall contains $98.4 \mathrm{~kg}$ of wood at $13 \%$ of water content (density of $480 \mathrm{~kg} / \mathrm{m}^{3}$ ). This corresponds to $97.1 \mathrm{~kg}(0.0971 \mathrm{t})$ of oven-dry wood. Considering that GHG emissions of $1 \mathrm{~m}^{2}$ of MHM wall are $35.23 \mathrm{~kg}$ $\mathrm{CO}_{2 \mathrm{eq}}\left(0.0326 \mathrm{t} \mathrm{CO}_{2 \mathrm{eq}}\right)$, while the GHG emissions for $1 \mathrm{~m}^{2}$ of brick wall are $85.90 \mathrm{~kg} \mathrm{CO}$ eq $\left(0.0859 \mathrm{t} \mathrm{CO}_{2 \mathrm{eq}}\right)$, the solved equation [30] for the displacement factor (DF) is:

$$
\begin{aligned}
\mathrm{DF}= & \frac{\text { GHG brick }- \text { GHG MHM }}{\text { Wood mass MHM }- \text { Wood mass brick }} \\
= & \frac{0.0859 \mathrm{CO}_{2 \mathrm{eq}}-0.0325 \mathrm{t} \mathrm{CO}_{2 \mathrm{eq}}}{0.0971 \mathrm{t}-0} \\
& =0.52 \mathrm{t} \mathrm{CO}_{2 \mathrm{eq}} / \mathrm{t}
\end{aligned}
$$

This means that for each $t$ of wood used to build a wall in MHM instead of bricks, $0.52 \mathrm{t} \mathrm{CO}_{2 \mathrm{eq}}$ of emissions are avoided. This value is low if compared to a previous study [30] in which a meta-analysis of greenhouse gas displacement factors of wood product substitution was performed. The authors found an average value of $3.9 \mathrm{t} \mathrm{CO}_{2 \mathrm{eq}}$ emission reduction. Yet the authors assert that the displacement factors vary widely between the 21 analyzed case-studies, due to differences in system boundaries between studies.

It is possible to quantify the reduced emissions in building a whole house with MHM system. To build a $100 \mathrm{~m}^{2}$ house, $40 \mathrm{~m}^{3}$ of wood are necessary (source: MHM producer), equal to $18.95 \mathrm{t}$ of oven-dry matter. As a consequence,
Table 4 Contributions of brick wall materials production process to global warming potential (GWP), ozone depletion potential (ODP), photochemical ozone creation potential (POCP), human

\begin{tabular}{|c|c|c|c|c|}
\hline Specific contributions & $\mathrm{GWP}\left(\mathrm{kg} \mathrm{CO} \mathrm{CO}_{2 \mathrm{eq}}\right)$ & $\mathrm{ODP}\left(\mathrm{mg} \mathrm{R} 11_{\mathrm{eq}}\right)$ & POCP $\left(g\right.$ Ethene $\left.e_{e q}\right)$ & $\operatorname{HTP}(\mathrm{kg} \mathrm{DCB} \mathrm{Dq})^{\mathrm{a}}$ \\
\hline Total & 85.904 & 7.318 & 41.628 & 19.461 \\
\hline Brick & 69.997 & 6.485 & 30.902 & 17.178 \\
\hline Manufacturing & 68.371 & 6.181 & 29.845 & 16.586 \\
\hline Transport & 1.626 & 0.304 & 1.057 & 0.592 \\
\hline Plaster & 4.206 & 0.392 & 2.017 & 0.963 \\
\hline Manufacturing & 3.747 & 0.306 & 1.718 & 0.796 \\
\hline Transport & 0.459 & 0.086 & 0.299 & 0.167 \\
\hline Light mortar & 0.592 & 0.027 & 0.174 & 0.098 \\
\hline Manufacturing & 0.563 & 0.022 & 0.155 & 0.087 \\
\hline Transport & 0.029 & 0.005 & 0.019 & 0.010 \\
\hline Polystyrene XPS ${ }^{b}$ panels & 9.741 & 0.334 & 8.173 & 1.036 \\
\hline Manufacturing & 9.687 & 0.324 & 8.138 & 1.016 \\
\hline Transport & 0.054 & 0.010 & 0.035 & 0.020 \\
\hline Mortar & 1.368 & 0.080 & 0.362 & 0.187 \\
\hline Manufacturing & 1.276 & 0.062 & 0.302 & 0.154 \\
\hline Transport & 0.092 & 0.018 & 0.060 & 0.033 \\
\hline Assembling (manually) & 0.000 & 0.000 & 0.000 & 0.000 \\
\hline
\end{tabular}
toxicity potential (HTP) for the production of $1 \mathrm{~m}^{2}$ of wall 
Table 5 Contributions to emissions of chemicals for the production of $1 \mathrm{~m}^{2}$ of Massiv-Holz-Mauer (MHM) and brick wall. The values are referred to the emissions after characterization ("Characterization" column) and before characterization ("Inventory" column)

\begin{tabular}{|c|c|c|c|c|c|c|c|c|}
\hline \multirow{2}{*}{$\begin{array}{l}\text { Classification } \\
\text { Global warming potential (GWP) }\end{array}$} & \multicolumn{4}{|l|}{ MHM wall } & \multicolumn{4}{|c|}{ Brick wall } \\
\hline & \multicolumn{2}{|l|}{$\begin{array}{l}\text { Characterization } \\
\mathrm{kg} \mathrm{CO}_{2 \mathrm{eq}}\end{array}$} & \multicolumn{2}{|l|}{$\begin{array}{l}\text { Inventory } \\
\mathrm{kg}\end{array}$} & \multicolumn{3}{|c|}{$\begin{array}{l}\text { Characterization } \\
\mathrm{kg} \mathrm{CO}_{2 \mathrm{eq}}\end{array}$} & $\begin{array}{l}\text { Inventory } \\
\mathrm{kg}\end{array}$ \\
\hline Emissions to air (total) & \multicolumn{2}{|l|}{35.23} & \multicolumn{2}{|l|}{32.65} & \multicolumn{3}{|c|}{85.90} & 80.98 \\
\hline Carbon dioxide & \multicolumn{2}{|l|}{27.61} & \multicolumn{2}{|l|}{27.61} & \multicolumn{3}{|c|}{78.93} & 78.93 \\
\hline Carbon dioxide (biotic) & \multicolumn{2}{|l|}{4.95} & \multicolumn{2}{|l|}{4.95} & \multicolumn{3}{|c|}{1.85} & 1.85 \\
\hline Nitrous oxide (laughing gas) & \multicolumn{2}{|l|}{0.37} & \multicolumn{2}{|l|}{$1.24 \mathrm{E}-03$} & \multicolumn{3}{|c|}{0.23} & $7.82 \mathrm{E}-04$ \\
\hline Sulphur hexafluoride & \multicolumn{2}{|l|}{0.03} & \multicolumn{2}{|l|}{$1.64 \mathrm{E}-06$} & \multicolumn{3}{|c|}{0.05} & $2.09 \mathrm{E}-06$ \\
\hline Methane & \multicolumn{2}{|l|}{1.99} & \multicolumn{2}{|l|}{0.08} & \multicolumn{3}{|c|}{4.64} & 0.19 \\
\hline Methane (biotic) & \multicolumn{2}{|l|}{0.19} & \multicolumn{2}{|l|}{0.01} & \multicolumn{3}{|c|}{0.18} & 0.01 \\
\hline Halogenated organic emissions ${ }^{a}$ & \multicolumn{2}{|l|}{0.08} & \multicolumn{2}{|l|}{$1.74 \mathrm{E}-05$} & \multicolumn{3}{|c|}{0.02} & $7.92 \mathrm{E}-06$ \\
\hline Ozone depletion potential (ODP) & & & $\mathrm{mg} \mathrm{R} 11_{\mathrm{eq}}$ & & $\mathrm{mg}$ & $\mathrm{mg} \mathrm{I}$ & $11_{\text {eq }}$ & $\mathrm{mg}$ \\
\hline Emissions to air (total) & & & 4.38 & & 2.66 & 7.32 & & 6.95 \\
\hline Halogenated organic emissions & & & 4.37 & & 2.66 & 7.32 & & 6.95 \\
\hline Long term to air (ethane, 1,1,2-trichl & luoro-, CFC-113) & & $1.17 \mathrm{E}-03$ & & $1.17 \mathrm{E}-0$ & $1.85 \mathrm{E}$ & -04 & $1.85 \mathrm{E}-04$ \\
\hline Photochemical ozone creation pote & & Ethene $_{\mathrm{eq}}$ & $\mathrm{g}$ & & & g Ethen & & $\mathrm{g}$ \\
\hline Emissions to air (total) & & 2.18 & & 5376.77 & & 41.63 & & 718.34 \\
\hline Group NMVOC ${ }^{\mathrm{b}}$ to air & & 1.61 & & 60.24 & & 25.39 & & 69.82 \\
\hline Sulphur dioxide & & 4.08 & & 85.07 & & 5.96 & & 124.11 \\
\hline Nitrogen oxides & & 1.97 & & 70.62 & & 4.56 & & 162.89 \\
\hline Carbon monoxide & & 3.61 & & 133.92 & & 4.46 & & 165.17 \\
\hline Carbon monoxide (biotic) & & 0.38 & & 4939.56 & & 0.10 & & 3.77 \\
\hline Methane & & 0.47 & & 79.74 & & 1.11 & & 185.40 \\
\hline Methane (biotic) & & 0.05 & & 7.63 & & 0.04 & & 7.23 \\
\hline Human toxicity potential (HTP) & & & & & $\begin{array}{l}\mathrm{kg} \\
\mathrm{DCB}_{\mathrm{ec}}^{\mathrm{j}}\end{array}$ & $\mathrm{kg}$ & $\begin{array}{l}\mathrm{kg} \\
\mathrm{DCB}_{\text {eq }}\end{array}$ & $\mathrm{kg}$ \\
\hline Emissions to air (total) & & & & & 9.71 & 0.41 & 19.46 & 0.46 \\
\hline Heavy metals to air ${ }^{c}$ & & & & & 5.01 & $2.39 \mathrm{E}-04$ & 6.40 & $3.52 \mathrm{E}-04$ \\
\hline Organic emissions to air (group VOC & $\mathrm{AH}^{\mathrm{e}}$, halogenated or: & rganic emiss & ns, other NMV & $\left.\operatorname{NOCs}^{\mathrm{f}}\right)$ & 2.46 & 0.06 & 3.36 & 0.06 \\
\hline Inorganic emissions to air $^{\mathrm{g}}$ & & & & & 1.68 & 0.16 & 9.17 & 0.30 \\
\hline Long term to air $^{\mathrm{h}}$ & & & & & 0.42 & $3.99 \mathrm{E}-04$ & 0.45 & $4.32 \mathrm{E}-04$ \\
\hline Particles to air (mainly $>\mathrm{PM}^{\mathrm{i}} 10, \mathrm{PM}$ & PM2.5) & & & & 0.15 & 0.19 & 0.08 & 0.10 \\
\hline
\end{tabular}

a Tetrafluoromethane, R 116 (hexafluoroethane), R 114 (dichlorotetrafluoroethane), R 22 (chlorodifluoromethane), Halon (1301), perfluoropentane, Halon (1211), R 113 (trichlorotrifluoroethane), R 134a (tetrafluoroethane), R 152a (difluoroethane), R 23 (trifluoromethane), R 12 (dichlorodifluoromethane), carbon tetrachloride (tetrachloromethane), R 124 (chlorotetrafluoroethane), chloromethane (methyl chloride), dichloromethane (methylene chloride), 1,1,1-trichloroethane, R 11 (trichlorofluoromethane), methyl bromide

b Non-methane volatile organic compounds

c Arsenic, chromium (+VI), nickel, antimony, cadmium, vanadium, copper, selenium, molybdenum, cobalt, thallium, chromium (unspecified), lead, mercury, zinc, tin, hydrogen arsenic (arsine)

${ }^{\mathrm{d}}$ Volatile organic compounds

e Polycyclic aromative hydrocarbon

${ }^{\mathrm{f}}$ Benzene, NMVOC (unspecified), ethylene oxide, propylene oxide, acrolein, formaldehyde (methanal), ethene (ethylene), toluene (methyl benzene), ethyl benzene, xylene (dimethyl benzene), phenol (hydroxy benzene), butadiene, xylene (meta-xylene; 1,3-dimethylbenzene), xylene (ortho-Xylene; 1,2-dimethylbenzene), Styrene

g Hydrogen fluoride, nitrogen oxides, barium, sulphur dioxide, beryllium, hydrogen chloride, ammonia, carbon disulphide, hydrogen sulfide, sulphur oxides

h Chromium VI, arsenic, nickel, vanadium, copper, beryllium, selenium, cadmium, cobalt, molybdenum, barium, lead, particulates $>10 \mu \mathrm{m}$, particulates $>2.5$ and $<10 \mu \mathrm{m}$, particulates $<2.5 \mu \mathrm{m}$, zinc, antimony, mercury, hydrogen sulfide, tin

i Particulate matter

j 1,4-dichlorobenzene 
considering the system boundaries used in this study, the emissions avoided for $100 \mathrm{~m}^{2}$ of MHM house when compared to a brick house of the equal dimension, are:

$18.95 \mathrm{t} \times 0.52 \mathrm{t} \mathrm{CO}_{2 \mathrm{eq}} / \mathrm{t}=9.85 \mathrm{t} \mathrm{CO}_{2 \mathrm{eq}}$

\section{Discussion}

These results are consistent with other studies comparing wood and different building materials which found wood to be among the most environmentally sustainable building material. It is remarkable though that most studies on this topic compare steel or concrete instead of brick to wooden walls or houses. Among the studies which compare timber and bricks, both Goverse et al. [21] and Monteiro and Freire [49] found a possible reduction in $\mathrm{CO}_{2}$ of almost $50 \%$ when using wood. In an application of value-focused thinking, Hassan [50] investigated three exterior wall types: masonry, concrete and timber. The functional unit the author chose for the LCA is $1 \mathrm{~m}^{2}$ of wall with $U$ value $0.2 \mathrm{~W} \mathrm{~m}^{-2} \mathrm{~K}^{-1}$. Although the brick and timber wall designs are different from those here analyzed, the wooden wall was proven to be the best option from an environmental perspective. In a case study of life-cycle $\mathrm{CO}_{2}$ emissions of a $137-\mathrm{m}^{2}$ single family house built in Austria either with a brick or wood frame, Kram et al. [51] determined in 2001 emissions of $18 \mathrm{t} \mathrm{CO}_{2}$ for the wood version and $27 \mathrm{t} \mathrm{CO}_{2}$ for the brick version. In this case, the wooden house emissions were one-third lower than those attributed to the brick house. However, specifications about the boundaries and sections of the walls were not given. On the other hand, Marcea and Lau [52] calculated the energy and $\mathrm{CO}_{2}$ cost of similarly performing residential buildings, finding that the brick assembly emitted 1.9 times more than the wooden assembly.

In this research the results show that the wooden wall emits nearly $60 \%$ less $\mathrm{CO}_{2 \mathrm{eq}}$ than the brick wall. As a consequence, the wood construction is confirmed to have a lower impact on global warming than the brick alternative, even if this case study is not directly comparable to the above cited studies because of the differences in system boundaries, functional unit (whole house and $1 \mathrm{~m}^{2}$ of wall) or for the variability in the brick wall and especially wooden wall designs, that usually are not even specified. Moreover, in terms of GWP, compared to the brick wall, the wooden wall has the additional benefit of acting as a carbon storage for all its lifetime. To better understand the contribution of carbon storage, a comprehensive carbon balance should be performed, including carbon sequestration in forest and biogenic emissions after the lifetime of the wood product. This would require a cradle-to-grave approach, which is outside the system boundaries of this study. Another aspect that should not be neglected when comparing the two systems is the weight of wood construction. The substitution of the traditional building materials with wood leads to large reductions in the weight of houses, which could substantially contribute to the dematerialization in the construction sector [20]. The difference of weight is high also between MHM wall and brick wall, with the former being about $60 \%$ lighter than the latter.

\section{Conclusions}

In this study an LCA was performed to assess the emissions to air caused by the production of materials used in a Massiv-Holz-Mauer (MHM) wooden wall and a brick wall. The results were compared to determine which of the two systems had the lowest environmental impacts.

For all the four impact categories considered, Global Warming Potential, Photochemical Ozone Creation Potential, Ozone Depletion Potential and Human Toxicity Potential, the MHM wall construction showed lower emissions to air compared to the brick wall. GWP and POCP represented, respectively, 40 and $77 \%$ of the traditional wall emissions, while ODP and HTP were, respectively, $60 \%$, and $50 \%$ of the emissions related to the brick wall building materials production. MHM was proven to be an extraordinary building material, which, while ensuring the same technical performance of bricks, is much more environmentally sustainable in terms of both global and local impact.

To further reduce the environmental impact of MHM, the main areas of improvement can be identified in the log processing, fibreboards manufacturing, and aluminium nails manufacturing for GWP and POCP. The energy production for the final assembling of the wall also caused a remarkable share of emissions. ODP was influenced by the emissions from the sawmill and from fibreboard and electricity production. Interventions on the aluminium nails production would also be critical in the reduction of the impact on HTP.

Overall, the use of MHM can represent a great opportunity to reduce the emissions in the construction industry. It was calculated that if bricks were replaced by MHM, for each oven dry $t$ of wood used to build a wall in MHM instead of bricks, $0.52 \mathrm{t} \mathrm{CO}_{2 \text { eq }}$ of emissions, equal to the displacement factor, would be avoided.

Acknowledgments Acknowledgements go to FBE Woodliving company and, particularly, to Giovanna Fongaro for making this study possible by sharing the data about their production and the knowledge about building with wood; and to Saviane Legno sawmill and in particular to Luciano and Paolo Saviane for having devoted their time during the data collection. 


\section{Compliance with ethical standards}

Conflict of interest The authors declare that they have no conflict of interest.

\section{References}

1. Ortiz O, Castells F, Sonnemann G (2009) Sustainability in the construction industry: a review of recent developments based on LCA. Constr Build Mater 23:28-39

2. Zabalza Bribián I, Valero Capilla A, Aranda Usón A (2011) Life cycle assessment of building materials: comparative analysis of energy and environmental impacts and evaluation of the eco-efficiency improvement potential. Build Environ 46:1133-1140

3. Morel JC, Mesbah A, Oggero M, Walker P (2001) Building houses with local materials: means to drastically reduce the environmental impact of construction. Build Environ 36:1119-1126

4. Edenhofer O, Pichs-Madruga R, Sokona Y, Farahani E, Kadner S, Seyboth K, Adler A, Baum I, Brunner S, Eickemeier P, Kriemann B, Savolainen J, Schlömer S, von Stechow C, Zwickel T (2014) IPCC 2014: climate change 2014: mitigation of climate change. Contribution of Working Group III to the Fifth Assessment Report of the Intergovernmental Panel on Climate Change. Cambridge University Press, Cambridge

5. Sartori I, Hestnes AG (2007) Energy use in the life cycle of conventional and low-energy buildings: a review article. Energy Build 39:249-257

6. Kayo C, Hashimoto S, Numata A, Hamada M (2011) Reductions in greenhouse gas emissions by using wood to protect against soil liquefaction. J Wood Sci 57:234-240

7. Noda R, Kayo C, Sasaki T, Takaoku S (2014) Evaluation of $\mathrm{CO}_{2}$ emissions reductions by timber check dams and their economic effectiveness. J Wood Sci 60:461-472

8. Noda R, Kayo C, Yamanouchi M, Shibata N (2015) Life cycle greenhouse gas emission of wooden guardrails: a study in Nagano Prefecture. J Wood Sci 62:181-193

9. Pajchrowski G, Noskowiak A, Lewandowska A, Strykowski W (2014) Wood as a building material in the light of environmental assessment of full life cycle of four buildings. Constr Build Mater $52: 428-436$

10. Bedon C, Rinaldin G, Izzi M, Fragiacomo M, Amadio C (2015) Assessment of the structural stability of Blockhaus timber logwalls under in-plane compression via full-scale buckling experiments. Constr Build Mater 78:474-490

11. Germano F, Metelli G, Giuriani E (2015) Experimental results on the role of sheathing-to-frame and base connections of a European timber framed shear wall. Constr Build Mater 80:315-328

12. Laguarda Mallo MF, Espinoza O (2015) Awareness, perceptions and willingness to adopt cross-laminated timber by the architecture community in the United States. J Clean Prod 94:198-210

13. Evans L (2013) Cross laminated timber-taking wood buildings to the next level. Eng News-Record 41:1-12

14. Urban jungle: wooden high-rises change city skylines as builders ditch concrete (2015). http://www.theguardian.com/artanddesign/ 2015/dec/12/wood-high-rise-buildings-urban-architecture-skylinesnew-york-city-oregon?CMP=share_btn_link. Accessed 02 Feb 2015

15. European Technical Approval ETA-13/0799 (2013) MHM-Wall elements. Österreichisches Institut für Bautechnik, Vienna

16. MHM production line. http://www.hundegger.de/en/machinebuilding/products/mhm-production-line. Accessed 21 Jan 2016

17. Li SH, Xie H (2013) Building professionals' attitudes towards the use of wood in building design and construction in Taiwan. Eur $\mathbf{J}$ Wood Wood Prod 71:497-505
18. Ximenes F, Grant T (2013) Quantifying the greenhouse benefits of the use of wood products in two popular house designs in Sydney, Australia. Int J Life Cycle Assess 18:891-908

19. Petersen AK, Solberg B (2005) Environmental and economic impacts of substitution between wood products and alternative materials: a review of micro-level analyses from Norway and Sweden. For Policy Econ 7:249-259

20. Buchanan AH, Honey BG (1994) Energy and carbon dioxide implications of building construction. Energy Build 20:205-217

21. Goverse T, Hekkert MP, Groenewegen P, Worrell E, Smits REHM (2001) Wood innovation in the residential construction sector; opportunities and constraints. Resour Conserv Recycl 34:53-74

22. Gustavsson L, Sathre R (2006) Variability in energy and carbon dioxide balances of wood and concrete building materials. Build Environ 41:940-951

23. Sathre R, O'Connor J (2010) A synthesis of research on wood products and greenhouse gas impacts, 2nd edn. Technical Report TR-19R, FPInnovations, Vancouver, B.C. ISBN 978-0-86488546-3

24. Upton B, Miner R, Spinney M, Heath LS (2008) The greenhouse gas and energy impacts of using wood instead of alternatives in residential construction in the United States. Biomass Bioenergy 32:1-10

25. Sathre R, Gustavsson L (2009) Using wood products to mitigate climate change: external costs and structural change. Appl Energy 86:251-257

26. Hennigar CR, MacLean D, Amos-Binks LJ (2008) A novel approach to optimize management strategies for carbon stored in both forests and wood products. For Ecol Manage 256:786-797

27. Pingoud K, Pohjola J, Valsta L (2010) Assessing the integrated climatic impacts of forestry and wood products. Silva Fenn 44:155-175

28. Lipkke B, Elaine O, Harrison R, Skog K, Gustavsson L, Sathre R (2011) Life cycle impacts of forest management and wood utilization on carbon mitigation: knowns and unknowns. Carbon Manag 2:303-333

29. United Nations Framework Convention on Climate Change (UNFCCC) (2003) Estimation, reporting and accounting of harvested wood products. Technical paper FCCC/TP/2003/7

30. Sathre R, O'Connor J (2010) Meta-analysis of greenhouse gas displacement factors of wood product substitution. Environ Sci Policy 13:104-114

31. Saavedra Flores EI, Dayyani I, Ajaj RM, Castro-Triguero R, DiazDelaO F, Das R, González Soto P (2015) Analysis of crosslaminated timber by computational homogenisation and experimental validation. Compos Struct 121:386-394

32. Lehmann S (2012) Sustainable construction for urban infill development using engineered massive wood panel systems. Sustainability 4:2707-2742

33. John S, Nebel B, Perez N, Buchanan A (2009) Environmental impacts of multi-storey buildings using different construction materials. Research report 2008-02. http://www.scnz.org/content/ events/docs/MAF\%20multistorey\%20building\%20report\%20Final $\% 208$ th\%20June\%202009.pdf. Accessed 23 Jan 2016

34. Chen YJ (2012) Comparison of environmental performance of a five-story building built with cross-laminated timber and concrete. Sustainable Building Science Program, University of British Colombia. http://sbsp.sites.olt.ubc.ca/files/2012/07/SBSPreport-Jessie-Chen.pdf. Accessed 23 Jan 2016

35. Robertson AB, Lam FCF, Cole RJ (2012) A comparative cradleto-gate life cycle assessment of mid-rise office building construction alternatives: laminated timber or reinforced concrete. Buildings 2:245-270

36. Paevere P, MacKenzie C (2006) Emerging technologies and timber products in construction-compendium of products and 
technologies. Australian Government-Forest and Wood Products Research and Development Corporation, Victoria, Australia

37. Bovea MD, Vidal R (2004) Materials selection for sustainable product design: a case study of wood based furniture eco-design. Mater Des 25:111-116

38. FBE Woodliving. Il muro di legno. http://www.fbe.it/1/sistema_ mhm_3513057.html. Accessed 17 Dec 2015

39. Corrado V, Ballarini I, Corgnati SP (2014) Building typology brochure-Italy (in Italian). Fascicolo sulla Tipologia Edilizia Italiana, nuova edizione, Politecnico di Torino-Dipartimento Energia Gruppo di Ricerca TEBE. http://episcope.eu/fileadmin/ tabula/public/docs/brochure/IT_TABULA_TypologyBrochure_ POLITO.pdf. Accessed 7 Jan 2016

40. Frischknecht R, Jungbluth N, Althaus HJ, Doka G, Dones R, Heck T, Hellweg S, Hischier R, Nemecek T, Rebitzer G, Spielmann $M$ (2005) The ecoinvent database: overview and methodological framework. Int J Life Cycle Assess 10:3-9

41. Bovea MD, Gallardo A (2006) The influence of impact assessment methods on materials selection for eco-design. Mater Des 27:209-215

42. Ljungberg LY (2005) Materials selection and design for development of sustainable products. Mater Des 28:466-479

43. GaBi 6 software (2011) PE International, Stuttgart

44. PAS 2050 (2011) Specification for the assessment of the life cycle greenhouse gas emissions of goods and services. British Standards Institution (BSI), London. (ISBN 978058071382 8)
45. Pierobon F, Zanetti M, Grigolato S, Sgarbossa A, Anfodillo T, Cavalli R (2015) Life cycle environmental impact of firewood production-a case study in Italy. Appl Energy 150:185-195

46. Core Writing Team, Pachauri RK, Meyer L, IPCC (2014): Climate change 2014: synthesis report. Contribution of Working Groups I, II and III to the Fifth Assessment Report of the Intergovernmental Panel on Climate Change. IPCC, Geneva, p 151

47. US EPA (1995) Profile of the nonferrous metals industry. Publ EPA/310-R-95-010, United States Environmental Protection Agency, Washington D.C.

48. US EPA (1997) Chapter 11: mineral products industry, section 11.3. Brick and structural clay product manufacturing, United States Environmental Protection Agency, Washington D.C.

49. Monteiro H, Freire F (2012) Life-cycle assessment of a house with alternative exterior walls: comparison of three impact assessment methods. Energy Build 47:572-583

50. Hassan OAB (2004) Application of value-focused thinking on the environmental selection of wall structures. J Environ Manag 70:181-187

51. Kram T, Gielen DJ, Bos AJM, de Feber MAPC, Gerlagh T, Groenendaal BJ, Moll HC, Bouwman ME, Daniels BW, Worrell E, Hekkert MP, Joosten LAJ, Groenewegen P, Goverse T (2001) The matter project-integrated energy and materials systems engineering for GHG emission mitigation. http://www.ecn.nl/ unit_bs/etsap/reports/ecn/pub01017.html. Accessed 16 Dec 2015

52. Marcea RL, Lau KK (1992) Carbon dioxide implications of building materials. J For Eng 2:37-43 